\title{
The Cooperation Complexity Rainbow: Challenges of Stakeholder Involvement in Managing Multinational Firms
}

\author{
Salman Kimiagari ${ }^{1,2}$, Samira Keivanpour ${ }^{1,3}$, Muhammad Mohiuddin ${ }^{1,2}$ \& Constance Van Horne ${ }^{4}$ \\ ${ }^{1}$ CIRRELT Interuniversity Research Center on Enterprise Networks, Logistics and Transportation, Canada \\ ${ }^{2}$ Laval University, Faculty of Business (FSA), Canada \\ ${ }^{3}$ Laval University, Faculty of Engineering (FSG), Canada \\ ${ }^{4}$ Zayed University, College of Business, Abu Dhabi, UAE \\ Correspondance: Salman Kimiagari, CIRRELT, Université Laval, Pavillon Palasis-Prince, bureau 2642, 2325, rue \\ de la Terrasse, Québec QC G1V 0A6, Canada. E-mail: Salman.Kimiagari@cirrelt.ca
}

Received: August 23, 2013

doi:10.5539/ijbm.v8n22p50
Accepted: September 16, 2013

Online Published: October 15, 2013

URL: http://dx.doi.org/10.5539/ijbm.v8n22p50

\begin{abstract}
Management of multinational enterprises is a complex and challenging task. This complexity also exists in managing value chains and interactionsamong interest groups. The objective of this paper is to highlight and present a theoretical framework on challenges that multinational corporations (MNC) face when integrating their stakeholders in management processes. In a multinational corporation, value-based management and long term value creationrequire the consideration of all stakeholders in the strategic decision-making process. Involving stakeholders is not only an activity aligned with social responsibility but also necessary for ensuring effective corporate governance. Establishing an appropriate strategy for stakeholder engagement raises several challenges for multinational firms. An extensive literature review resulted in the development of aconceptual framework which can be used for addressing these challenges. The essential issues of this framework are presented in four categories: relationships, environmental context, management (including structure and strategy issues) and stakeholder engagement. Future research might involve a large scale survey to enhance our understanding of the issue and empirically test our theoretical framework.
\end{abstract}

Keywords: multinational firms, stakeholder engagement, challenges, relationship configuration, environmental context, strategy and structure

\section{Introduction}

Openness of markets, freeing up capital flow and globalization of production have created an interdependent world in the post-industrial era of today. These enhanced exchanges have created acomplex business environmentwhich poses increasing challenges developing a sustainable socioeconomic and environmental strategy for business executives (Svendsen \& Laberge, 2005). In such a challenging environment, organizations need to develop new ways of thinking and manage with the active involvement of stakeholders. Enhanced globalization and interdependence have transformed the landscape of stakeholder engagement in firm management processes. In this context, relationships within and across boundaries are important for managers, and especially for multinational firms. Furthermore, advances in computer and communication technologies, and operationsacross different time zones, countries, languages and organizationspresent new network realities that have changed the stakeholder engagement approaches in today's business field.

Based on the World Values Survey, authors (Inglehart et al., 1998) assert that general public trust in leaders is decreasing and people prefer to be directly involved in the decision making processes which affect them. Information and communication technologies (ICT) have facilitated sharing information and exchanging knowledge at little cost, in real time and beyond geographical boundaries (Koopman, 1990; Al-Azad et al., 2010). In this networked world, pressure of participants and the enabling power of technology, push organizations to involve stakeholders in their strategic decision-making process.

Maximizing shareholdervalue is the essential objective of firms (Lazonick \& O'Sullivan, 2000; Laplume, Sonpar \& Litz, 2008; Kennerly, 2010; Karuranga et al., 2011). However, this maximization needs to also consider the value created by and for stakeholders. Depending on the location and local context, subsidiaries of multinational firms might have different types of governance choices. In this way, the value created through interaction with 
stakeholders is considered the only objective function for the corporation (Jensen, 2002). According to authors such as Cyert and March (1963), Ansoff (1965), and Bower (1970), economic decisions at the firm level require that noneconomic (managerial and behavioral) factors be understood (Barton, 1987). This assertion recognizes the role of non-equity stakeholders in the value creation of multinational firms.Furthermore, interaction with stakeholders is a strategic choice (Berman et al., 1999), using this, corporate-level strategic decisions are formulated from complex interactions between individuals with different interests, values and different perceptions (Bower, 1970).

Increasing attention to corporate social responsibilities (CSR) of MNCs both in international management research and in public debate is also another pressure for stakeholder's involvement. According to Reimann et al., (2012), the increasing footprint of MNCs in the world's emerging economies led to increased attention to their CSR strategies. Based on the study conducted by (Boulouta \& Pitelis, 2013), CSR can make a significant positive contribution to national competitiveness. Hence, the building blocks of CSR can influence not only MNCs performance but also their competitive advantage. Kang (2013) studied relationships between corporate diversification and corporate social performance (Thompson et al., 1991). He proposed that diversified firms face and address a wider range of stakeholder demands and social issues than focused firms. He explained that these firms face heavy stakeholder demands that increase their financial constraints. According to (Kaptein \& Wempe, 2002), "business code is a policy document that defines the responsibilities of the corporation towards its stakeholders and/or the conduct the corporation expects of employees". Recently, Kaptein (2004) conducted a study related to multinational firms. The author concluded that among thetwo hundred largest companies in the world, $52.5 \%$ have a code. And based on the study, a stakeholder statute is common among $72 \%$ of studied firms.

Based on these perspectives, it is crucial for multinational companies to consider the different aspects of stakeholder involvement, and deal with the relevant challenges. In this paper, we reviewthese challenges and propose a framework to address them. The role of local subsidiaries, environmental context, organizational structure and strategy, relationship configurations between different actors and stakeholder engagementare addressed to highlight relevant challenges (Castro, Verde, Salvadó \& Navas-López, 2013).

Based on the different features of stakeholder involvement a variety of theories need to be addressed in this work. These theories include: organizational theory, stakeholder theory, system theory, corporate planning theory, and social responsibility. In this article, we use anextensive literature review to develop the framework and to explainits different elements. The outline of this paper is as follows. In section two we review the theoretical base of this study and related studies. Following, we present the conceptual framework and the detailed elements. Finally, in section four, we conclude with some comments and avenues for future research.

\section{Theoretical Perspective on Role of Stakeholders in MNC Management}

There is no doubt of the prominence of MNC in the international business arena. Thanks to their important role in the world economy, much attention has been given to MNCs, including the raison d'être of their existence; their influence upon politics, culture, and industries; and their structure, strategies, management and value chains. Literature that addresses the importance of social and environmental responsibilities for multinational firmsis abundant. These studies provide managerial insights with respect to the role of stakeholders and corporate responsibilities in MNCs (Zyglidopoulos, 2002; Riahi-Belkaoui, 2003; Husted \& Allen, 2006; Frynas, 2005).

According to Zyglidopoulos (2002), multinational corporations face higher environmental and social responsibility than their national counterparts due to the concern of international reputationwhicheffects their reputation in markets everywhere, as well as the concern of foreign stakeholder salience. Further,the managerial implications considering the social and environmental responsibilities of multinational firms have at least two consequences. First, the challenges regarding the stakeholdersof subsidiaries and their relationship with headquarter of the MNC. The second is the impact on a firm's reputation beyond host markets. The inability to identifykey local stakeholders in subsidiaries can put the firm's reputation at risk in other markets in addition to the host market (Davies, Chun \& Kamins, 2009). Therefore, an integrated approach for considering stakeholders from the subsidiaries as well as from headquarters should be adopted. However, literature on integrating the various types of stakeholders into the governance system of the MNCs remains considerably less explored (Wang, 2010). In this section we provide a theoretical base of stakeholder studies.

\subsection{Stakeholder Theory}

Freeman \& McVea (2001) studied the building blocks of stakeholder theory from different theoretical perspectives; corporate planning, system theory, and social responsibility. In this subsection, we summarize the literature in each related theory. Stakeholder theory begins with the statement that values are necessarily and explicitly a part of doing business (Freeman, 2004) and that stakeholder theory can be seen as an integrating theme 
for business (Jones, 1995). Stakeholder theory is also considered as a framework statement to study the link between the social performance and financial performance of firms (Ruf et al., 2001). Brenner and Cochran (1991; p.452) offered a "stakeholder theory of the firm" for two purposes. First, the theory describes how organizations operate and second, it helps predict organizational behavior. Donaldson \& Preston (1997) defined three characteristics of stakeholder theory; normative, instrumental and descriptive with these three aspects being mutually supportive.

Stakeholder theory is a competing theory of the firm (Key, 1999) to traditional views. Based on Key's work, theoretical discussion on stakeholder theories have continued to concentrate on the types of relationships between business and society, and the business systems within society. Moreover, he found that stakeholder theory remains focused on the actors in the environment (Key, 1999). Freeman (1984) notes that stakeholder theory has developed within four different management research themes over the last thirty years; it was developed by organizing the related stakeholder concepts including corporate planning, systems theory, corporate social responsibility and organizational theory. These theories together have created the framework of the stakeholder approach in strategic management literature in the 1980s.

Harrison and St. John (2009) split the organizational environment into two; the operating environment inside the firm and the broader environment outside the firm. Freeman \& McVea (2001) studied the internal stakeholders such as employees and managers with resource based theory and applied Porter's five-force model for external stakeholders. Ansoff (1965) explained the importance of identifying critical stakeholders, although he considered stakeholders as the hurdles of achieving the main objectives of the firm. According to Freeman \& McVea (2001), stakeholders need to create limits on the actions firms for the betterment of firms in the long run. This implies that management should be aware of the need of stakeholders to assist in setting the boundaries of a firm's actions.

There are two main fundamentals in corporate planning according to Freeman \& McVea (2001); prediction and adaptation. Firstly, senior executives or specialist research firms on their behalf, carry out an analysis of the business environment to identify the trends and elaborate their future predictions of the firm. This in turn helps to formulate the future strategies to adapt and reap advantages from the evolving business environment by putting the firm in a competitive position. This corporate planning stage also conducts the stakeholder analysis while doing the environmental scanning to highlight the trends of the business environment. According to Freeman and McVea (2001), the "corporate planning approach" also has some disadvantages such as the generic level of analysis and the use of analytical techniques. This generic analysis leads to generic strategies regardless of industry or context of the firm and the analytical tools add more complexity to measuring economic parameters (Kimiagari \& Montreuil, 2013). This implies that features of strategy are often difficult to quantify.

Systems theory asserts that the planning of a system entails the design of a desired future and effective ways to acheive it (Ackoff \& Churchman, 1947). It is generally understood that an enterprise is an open system of decisions and in this system we need to achievecertain goals.Goalsarea function of efficiency, effectiveness and environmental variables. Ackoff (1970) considered stakeholders as an environmental variable. Freeman \& McVea (2001) stated systems theory focuses on the external linkswhich are an important part of every firm. This indicates that firms can be considered as"open systems" which are part of a larger network rather than as independent entities.

However, both systems theory and organization theory suffer some limitations in their approaches to explaining the business environment (Freeman \& McVea, 2001). First, due to thecollectivist nature of thetwo approaches, it is difficult to incorporate the autonomy of the firm. Second, when problems are expressed there is no clear beginning or ending point to the analysis. However, the authors concluded that despite the essential problems in applying these ideas, these approaches were essential to emphasize the importance of enlarging the analysis of strategic problems by including all stakeholders (Freeman \& McVea, 2001).Freeman and McVea (2001) assert that the rise of social responsibility literaturehas accelerated to extend to the stakeholder analysis in the field of strategic management. They highlight that many corporate social responsibility (CSR) initiatives have concluded that stakeholder relationships are often limitations as highlighted in the corporate planning literature (Michailides \& Lipsett, 2012). They at test that there are diver gences among researchers in the corporate social responsibility literature regarding the priorities of stakeholders. According to many researchers (Shrivastava \& Grant, 1985; Abd Karim, Abdul Rahman, Ali Berawi \& Jaapar, 2007), all stakeholders are equally important as they all have moral standing. This implies that an integrated stakeholder approach might include a bundle of interacting, reinforcing and contradicting theories of business strategy which would need to be based on concrete studies of real business case studies (Freeman \& McVea, 2001). 


\subsection{Stakeholder Engagement}

Developing a sustainable business strategy in the face of increased volatility in the global business environment has deeply influenced the way in which executives think of non-equity partners and how to include them in the governance process. According to Amaeshi and Crane (2006), one of the important tasksin managing any MNC is to manage relationship between the firm and its surrounding environment, including different stakeholders, to enhance the effectiveness of the firm's decisions and strategies.

There are different practices for stakeholder engagement such as the Gable (2005) model. Gable's (2005) model presented three phases of the stakeholder engagement process. Phase one treats "Internal Preparation". In this phase, the organization tries to find the right leader; build/train its team; measure the company's baseline performance and the public's perceptions of its performance and then the organization should continue to phase two. Inthe second phase issues such as stakeholder mapping and strategic planning are dealt with. Organizations try to account for their stakeholders; map stakeholder roles according to business objectives; analyze the results and draw the results collectively into a strategic plan. Finally, in the third phase stakeholder engagement is dealt with, where it is the duty of the organization to develop a stakeholder engagement plan to reach business objectives; measure and monitor results and communicate results appropriately (Gable, 2005).

\section{Challenges of Incorporating Stakeholders in MNC Governance}

The rise of globalisation, a multi-polar business world and the consciousness of stakeholders have placed MNCs in front of challenges they need to overcome to survive and maintain market position. These challenges can be categorised into four aspects; relationships, environmental context, managerial aspects and stakeholder engagement.

\subsection{Relationships}

The first group of challenges concern relationships. As Figure 1 illustrates, there are different key players and stakeholders from different local and global context and that this can be a source of conflict. The configuration of relationships between headquarters, and local and global stakeholders can raise many challenges for multinational firms. For example, figure 2 shows two different configurations of relationships, central configuration or network shape. The network configurationadds more complexity to the value analysis and stakeholder engagement process and consequently leads to increased complexity when measuring performance.

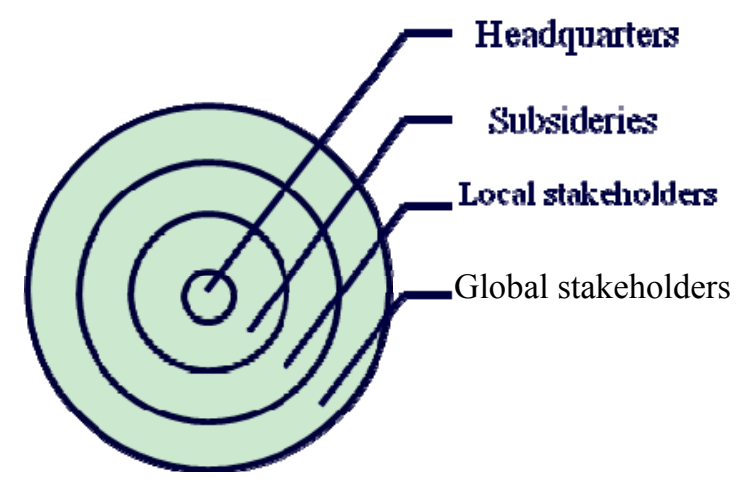

Figure 1. The key players in multinational firms 


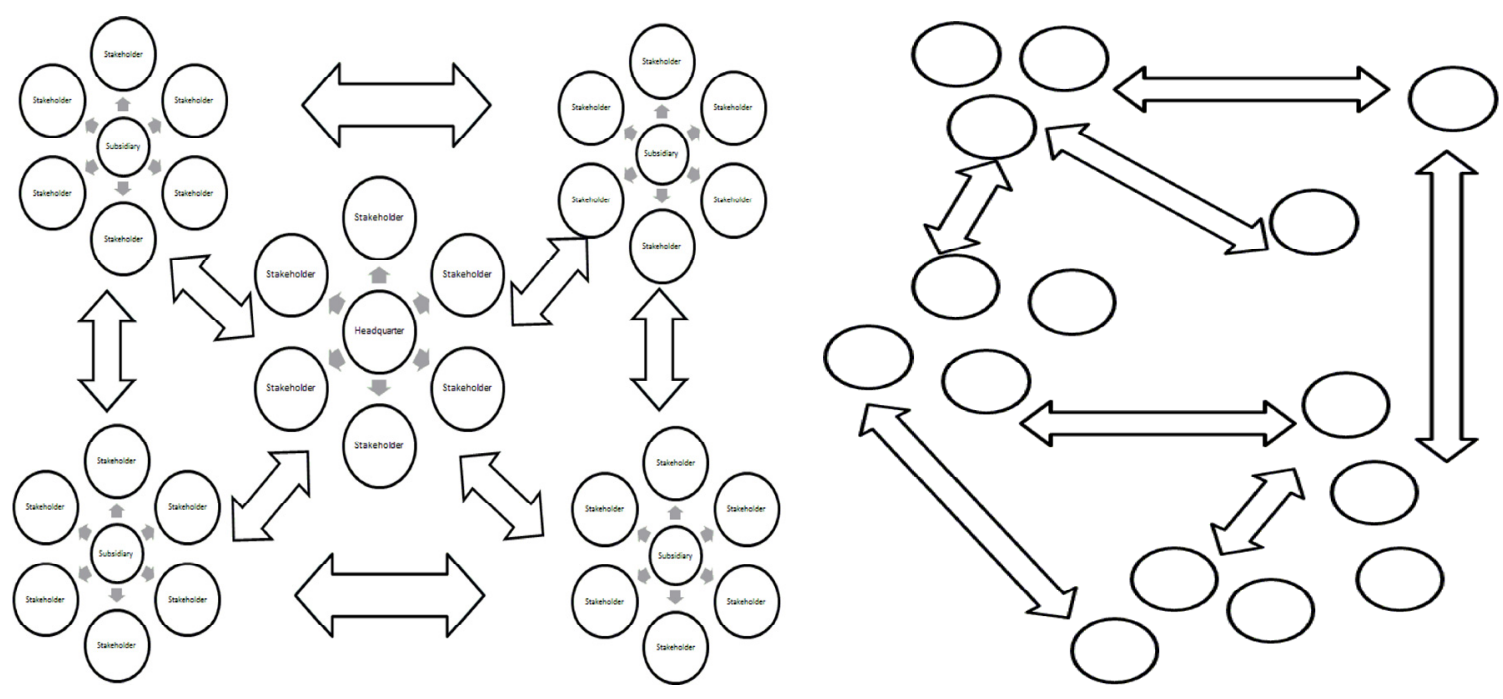

Figure 2. Configuration of players in multinational firms

It is clear that the relationship framework between firms and their stakeholders can be built based on a classification of the attributes of stakeholders. Mitchell and Wood (1997) consider this a narrow view of stakeholder theory. They explain that 'narrow views of stakeholders' arose due to shortages in adequate resources, time and attention as well as the limited patience of managers to deal with external hurdles. They state that narrow views of stakeholders try to describe relevant groups in terms of their direct relevance to the firm's core economic interests. Mitchell and Wood (1997) propose that classes of stakeholders can be identified by their possession or perceived possession of one, two, or all three of the following attributes: (1) the stakeholder's power to influence the firm, (2) the legitimacy of the stakeholder's relationship with the firm, and (3) the urgency of the stakeholder's claim on the firm. Figure 3 illustrates these classes.

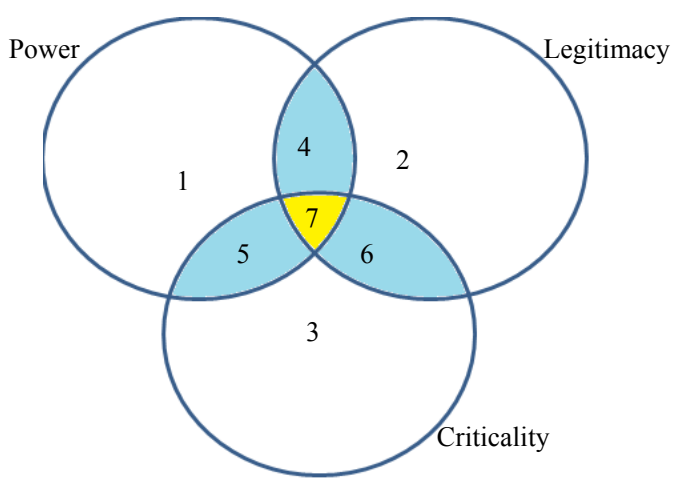

\begin{tabular}{lll}
\hline & 1) & Dormant Stakeholder \\
Latent Stakeholder & 2) & Discretionary Stakeholder \\
& 3) & Demanding Stakeholder \\
& 4) & Dominant Stakeholder \\
& 5) & Dangerous Stakeholder \\
Expectant Stakeholder & 6) & Dependant Stakeholder \\
& & \\
Definitive Stakeholder & 7) & Definitive Stakeholder \\
\hline
\end{tabular}

Figure 3. Stakeholder identification (adapted from Mitchell \& Wood, 1997) 
Latent stakeholders possess only one of the aspects of power, legitimacy, or criticality, and contain dormant, discretionary, and demanding stakeholders. Expectant stakeholders possess two different features, and include dominant, dependent, and dangerous stakeholders (Mitchell \& Wood, 1997). Definitive stakeholders possess all three attributes. The sorting relationship with stakeholder based on the narrow view is outlined in Table 1 .

Table 1. Sorting relationship for stakeholder identification (adapted from Mitchell \& Wood, 1997)

\begin{tabular}{lll}
\hline No & Relationship type & Category \\
\hline $\mathbf{1}$ & The firm and stakeholder are in relationship & A Relationship Exists \\
$\mathbf{2}$ & The stakeholder exercises voice with respect to the firm & \\
$\mathbf{3}$ & The firm is dependent on the stakeholder & Power Dependence: Stakeholder Dominant \\
$\mathbf{4}$ & The stakeholder has power over the firm & \\
$\mathbf{5}$ & The stakeholder is dependent on the firm & Power Dependence: Firm Dominant \\
$\mathbf{6}$ & The firm has power over the stakeholder: & \\
$\mathbf{7}$ & The firm and stakeholder are mutually dependent: & Mutual Power-Dependence Relationship \\
$\mathbf{8}$ & The firm and stakeholder are in contractual relationship & Basis for Legitimacy of Relationship \\
$\mathbf{9}$ & The stakeholder has a claim on the firm & \\
$\mathbf{1 0}$ & The stakeholder has something at risk & \\
$\mathbf{1 1}$ & The stakeholder has a moral claim on the firm: & Stakeholder Interests-Legitimacy Not Implied \\
$\mathbf{1 2}$ & The stakeholder has an interest in the firm &
\end{tabular}

\subsection{Environmental Context}

The environment context is the second source of challenges, as dealing with different stakeholders in different cultural or political background raises many issues for multinational firms. It is without doubt that the effective involvement of stakeholders requires appropriate dialogue and negotiations with interested parties. Different cultural and political frameworks complicate these negotiations, bargaining, and dialogue. As we explained previously, there are many different players in the issue of stakeholder engagement in international firms. Based on Allison (1971) these players need an environment to operate, further he explained that the environment is where the game is played (p. 171) and that the structure of the game is created by the power that is shared by individuals with separate responsibilities (p. 171).

The literature of challenges in multinational enterprises can be classified into categories including ethics, communication culture and human resources (Colakoglu, Tarique \& Caligiuri, 2009; Sultana et al., 2013). General topics on business ethics concern formation, stakeholder theory and leadership. Enderle (1999) addressed the ethical challenges in a context of international business. Differences in the ethical perception of managers, the role of local values in business activities, influences from national values, globalization problems and different culture and religions are also explained in his work.

Gary (2009) describes the cultural issues in multinational context as communication across culture including language and nonverbal communication, cultural values, negotiating across cultures, national cultural power distance and organizational cultural distance. Chew (2004) highlights some human resource management challenges of multinational firms. He mentions that the issues facing MNCs include failed assignments due to poor expatriation management policies and inadequate training before and during the mission abroad. In consequence, the expatriates return abruptly and earlier than they were scheduled to and thus the MNCs become unable to re-integrate them into headquarter and loose valuable knowledge and experiences gained during the expatriation period abroad. He concludes that crises in expatriate management can threaten a firm's capabilities and performance in the host country (Geringer, Beamish \& Dacosta, 1989). The industrial context of the firm and local forces can also raise challenges (Matei \& Mohiuddin, 2010). For example there is environmental legislation in specific countries which is greatly supported by local populations, not considering these stakeholders at an early stage of the product development design phase can lead to product failure at a local level or even pose a risk for the reputation of headquarters.

\subsection{Management}

Organizational structure and strategy are two important topics in stakeholder engagement. Some crucial challenges are related to the strategy of the actors. Subsidiaries and headquarter are the main players in this game. The strategy typology of subsidiaries and structure of multinational firms are key issues in involving stakeholders. In this section we explain the details of these issues. 


\subsubsection{Organizational Structure}

To review the structure of multinational firms, it is valuable to consider the core conceptual works in organization structure theory. Simon (1945) explained that a basis for authority relations is always employed in connection with a hierarchy of authority and functionalization involves the analysis of each objective of an organization into subsidiary objectives. One or more of the subsidiary objectives may be assigned to each organizational unit. There will be a hierarchy of functions and objectives corresponding to the hierarchy of divisions and bureaus in the organisation.

Chandler (1962) formulated hierarchy and documented the rise of the 'M-form' organization where units are responsible for their own operational decision making. In this organization form, there is a headquarters unit which is responsible for strategic decisions and monitoring the performance of all divisions. However, this hierarchical model was unable to adequately address the full complexity of the MNC (Birkinshaw, 1995). Therefore, Birkinshaw (1995) introduced an alternative organizational theory of the MNC, labelled heterarchy. There are three aspects of heterarchy that distinguish it from the hierarchical model of organization. In the heterarchical model resources, managerial capabilities and decision making power are dispersed throughout the organization, instead of concentrating at the top. Second, there are lateral relationships between subsidiaries, in terms of product, people and knowledge flows and third, activities are coordinated along multiple dimensions, typically geography, product and function (Birkinshaw, 1995).

Research on multinational corporations has demonstrated that its internal structure is not homogeneous, rather it is systematically differentiated depending on contextual environmental differences (Ghoshal, 1989). Thompson (1967) proposed that 'under norms of rationality', organizations facing heterogeneous task environments seek to identify homogeneous segments and establish structural units to deal with each of them. The multinational corporation is therefore the model case of an organization facing heterogeneous task environments (Ghoshal, 1989).

Ghoshal (1989) defined a four quadrant classification for the contextual conditions faced by the subsidiary in headquarters-subsidiary relationships as follows: i) low environmental complexity and low local resource levels; ii) low environmental complexity and high local resource levels; iii) high environmental complexity and low local resource levels and, iv) high environmental complexity and high local resource levels. Ghoshal (1989) presented them based on joint conditions: a) environmental complexity and b) local resources. Each situation demonstrated a case based on the nature of dependency and interdependency in the exchange relationship between the headquarters and the subsidiary, and consequently, each situation represents a different structural schema. In Ghosal's hypothesized fit, his schema of four structures is based on three indexes. These indexes are centralization, formalization and socialization and each fit structure is labelled as illustrated in Figure 4.

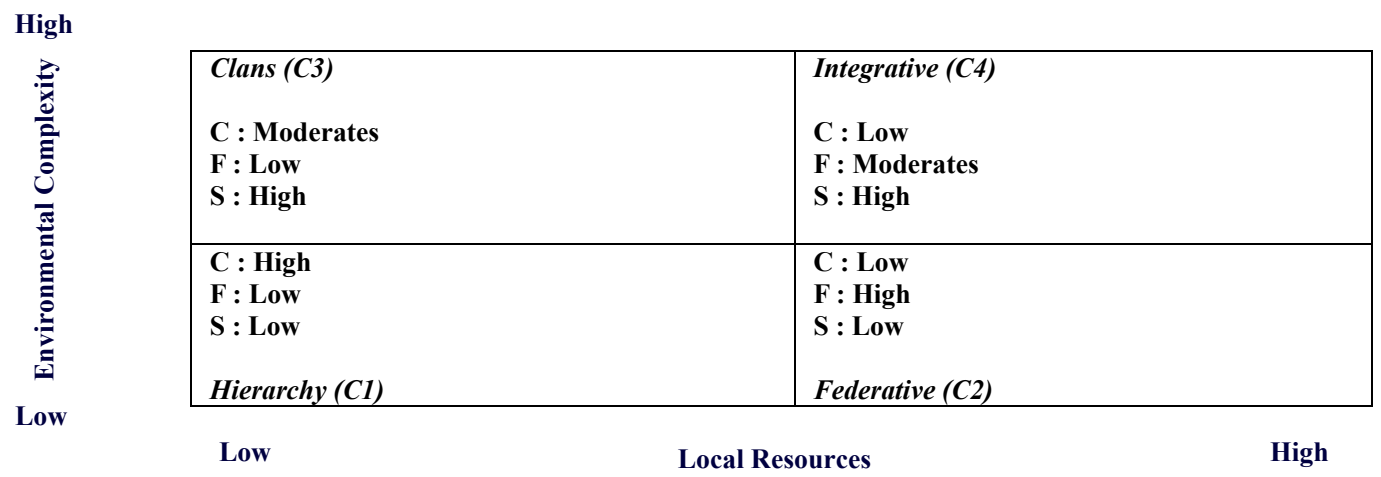

Figure 4. Structure of headquarters-subsidiary relation (Ghoshal, 1989)

The engagement of stakeholders needs an appropriate response to their needs and requests, which affects the homogeneity of internal structures in multinational firms. In addition, dealing with local stakeholders requires increased authority and flexibility in subsidiaries, yet this can also raise challenges for headquarters in monitoring and the strategic decision making process. Based on Ghoshal's (1989) model indexes, stakeholder engagement necessitates a high degree of socialization, low centralization and moderate formalization or an integrative form, but a high degree of local resources may not be possible for each subsidiary and thus can lead to limited flexibility. 
Stakeholder engagement requires agility and quick responsiveness built into organizational structure. As a result, there is a need to account for a degree of contingency in organizational structure of multinational firms when considering an active role for stakeholders, however designing such structures could be challenging for multinational companies.

\subsubsection{Strategy}

Subsidiaries are crucial actors in MNCs. According to Birkinshaw (1998), a subsidiary is a value-adding entity in a host country. Based on his view this definition reflects the reality that a given host country will sometimes have several subsidiaries (of the same parent) that are independent of one another and that, consequently, will have a separate evolutionary paths.

Birkinshaw (1998) classifies the subsidiary strategy typology in three categories (Figure 6). In the local implementer, the subsidiary has a limited geographic scope, typically a single country, and a severely constrained product or value-added scope (Birkinshaw, 1995). As a local implementer, foreign subsidiaries seek to meetatypical local needs in products, channels, and marketing practices in each country (Porter, 1986). In this context, the subsidiary's role is to adapt global products to the needs of the local market.

The global mandate manages local responsiveness and global integration simultaneously. In this model, subsidiaries achieve 'decentralized centralization'; activities are integrated worldwide, but managed by the subsidiary, not from headquarters (Birkinshaw, 1995). The specialized contributor integrates competitive positions across national markets. The subsidiary has considerable expertise in certain specific functions or activities, but its activities are tightly coordinated with the activities of other subsidiaries (Birkinshaw, 1995). Kim (2005) explained that as a specialized contributor, a foreign subsidiary is highly dependent on headquarter and highly interdependent with other subsidiaries within the same MNC. Subsidiary as a 'local implementer' needs to deal with local suppliers to meet local production needs. Subsidiary with the role as a 'world mandate' need to establish appropriate strategies in interaction with global competitors and global players. The other one as a 'specialized contributors' needs to deal with local shareholders and shareholders of other subsidiaries of the same MNC. The MNC as a whole needs to be concerned not only with its shareholders, but also the stakeholders in different levels dispersed wherever it has at least one subsidiary organization.

Another seminal work on multinational strategy management is the work of Rugman (2005). He developed matrix strategies for assessing the top 500 multinational firms. Figure 6 illustrates the important factors that influence the strategy of multinational firms. The environmental context includes the host country and other legal boundaries as well as organizational structure, and these also are important factors which influence the strategies of MNCs. The relevant challenges with respect to organizational structure and environmental context have been addressed in previous sections. The competitive advantages of firms and the types of product, for example; the case of global products, determine how much companies are under social and environmental responsibilities and pressures. Furthermore, the number of stakeholders engaged in local subsidiaries and the intensity of engagement can also affect the strategy typology of multinational firms. The variety of non-shareholder stakeholders and the degree of participation from communications to partnerships can also influence the strategic choice of multinational companies (Frooman, 1999).

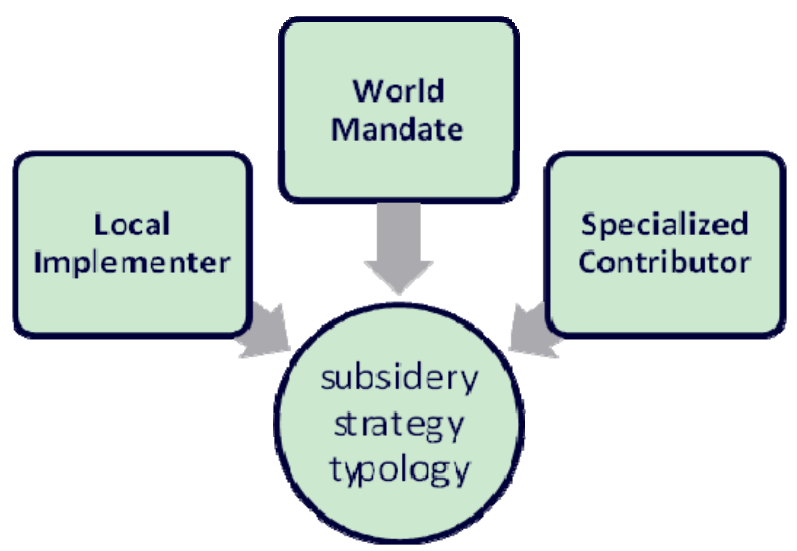

Figure 5. Subsidiary strategy typology based on Birkinshaw (1998) 


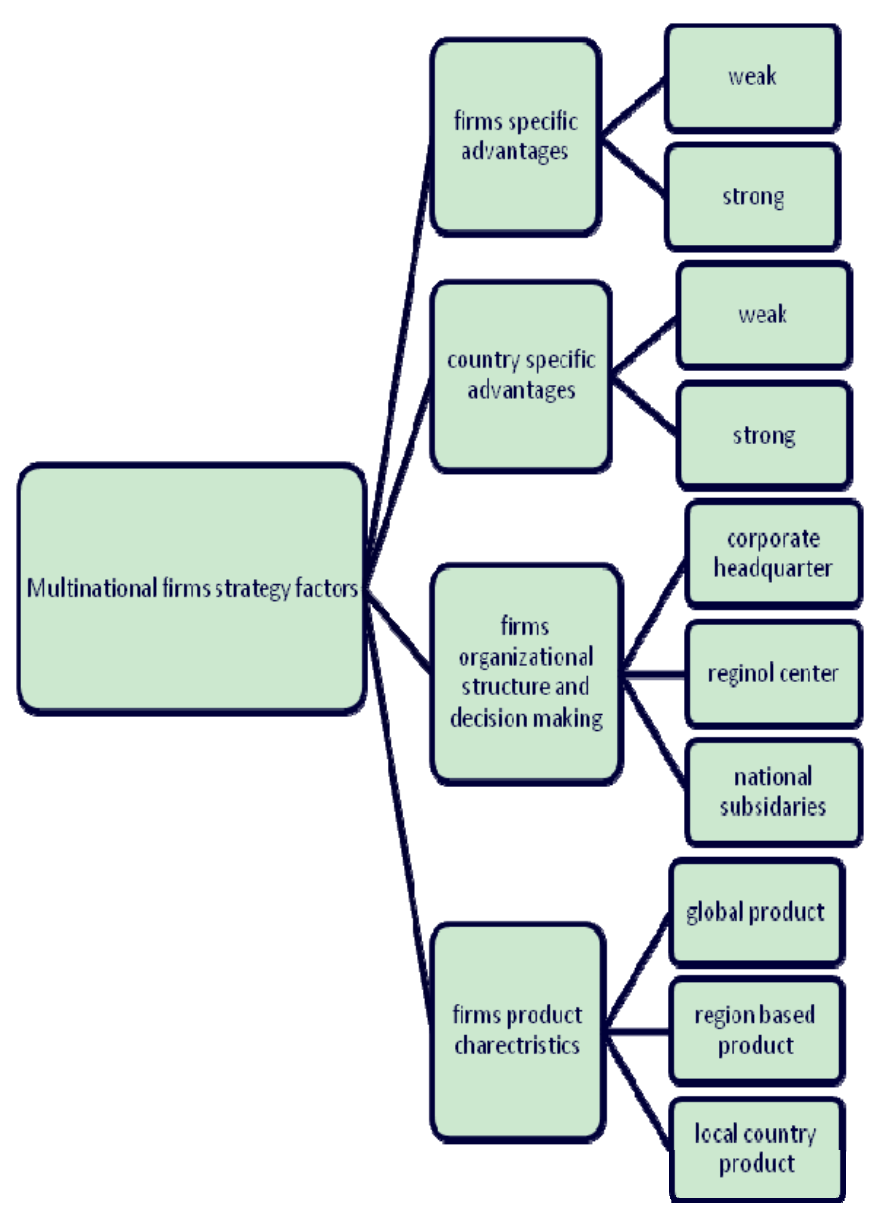

Figure 6. Multinational firms' strategy factors based on Rugman (2005)

\subsection{Stakeholder Engagement Performance}

Similar to any other business activity, stakeholder engagement needs to be managed. This management should have a clear plan and a set of objectives, budget and responsibilities. Defining the priorities for strategic formulation and assigning different roles to them or the level of participation in decision making, as a reviewer or advisor, the degree of informative stakeholders or negotiation and bargaining groups are the other challenges in strategic formulation and implementation.

Priorities concerning stakeholders vary based on whether firms view themselves and stakeholders as interdependent entities (Brickson, 2005). When firms cross territorial borders, they are faced with different contexts, stressing the differences between the subsidiary and the host-country context and increasing the boundaries with local actors. This could decrease perceptions that the subsidiary and its local stakeholders belong to a common group aiming for the same objective (Crilly, 2011).

Based on five important steps of strategic planning including setting mission and objectives, environmental scanning, strategy formulation, strategy implementation and evaluation and control (Grant, 2003), we can observe the challenges of stakeholder engagement in the execution phase. This stage of multiple players requires a multiple objective framework, which in turn complicates the unique definition of objectives. Considering the varieties of local and global stakeholders, their interests and their value perception are challenging issues. Table 2 outlines the different stakeholders and their regional context. Moreover, defining the priorities for strategic formulation and assigning the different roles to them or the level of participation: involvement in decision making, involvement as reviewer or advisor, informative stakeholders or negotiation and bargaining, are the other source of challenges. 
Table 2. Stakeholders and regional context

\begin{tabular}{lll}
\hline No & Stakeholders & Regional context \\
\hline $\mathbf{1}$ & Political groups & Host country \\
$\mathbf{2}$ & Government & Host country \\
$\mathbf{3}$ & Suppliers & Home or host country or a third country \\
$\mathbf{4}$ & Competitors & Home and host country \\
$\mathbf{5}$ & Employees & Home and host country \\
$\mathbf{6}$ & Unions & Host country \\
$\mathbf{7}$ & Customers & Host country \\
$\mathbf{8}$ & Owners & Home or host country \\
\hline
\end{tabular}

Based on the plan-do-check-action or PDCA cycle (Moen \& Norman, 2006) and Gable's (2005) model, the different challenges in stakeholder involvement process are addressed in Figure 7.

The first phase in stakeholder engagement is planning. This planning includes the internal preparation of both subsidiaries and headquarters. In this phase, some challenges can occur. First, planning needs clear definition of goals and objectives. The variety of local stakeholders and global stakeholders makes the definition of goals and objectives difficult. Conflict among different may occur. Planning also requires identifying value from a stakeholder perspective. This can be challenging. The second phase is execution. This phase includes stakeholder mapping, strategic planning and stakeholder engagement. The relevant challenges in this phase are identification of key stakeholders and their priorities. This could add an additional source of conflict. Identifying the intensity of the relationship, from dialogue to partnership in addition to communication challenges, is considerable in this phase. The last phase is establishing the monitoring and action plan. Identifying adequate performance metrics for monitoring and measuring stakeholder satisfaction is difficult for multinational companies.

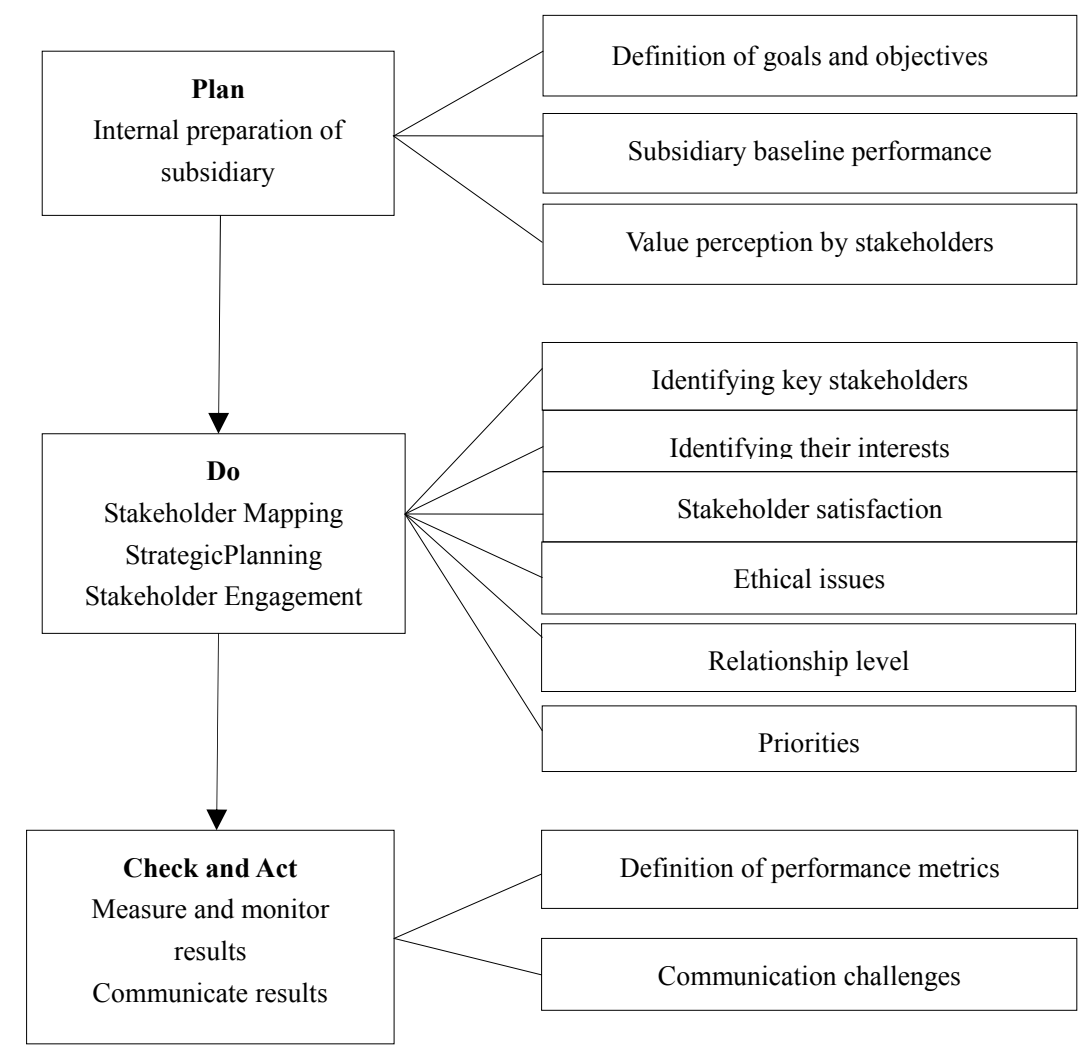

Figure 7. Stakeholder involvement in multinational firms and relevant challenges

\subsection{Conceptual Framework: Challengesof Stakeholder Integration in MNC Management Processes}

Based on the findings in previous sections, Figure 8 presents the conceptual framework that addresses the 
challenges of incorporating stakeholders into MNC management processes.

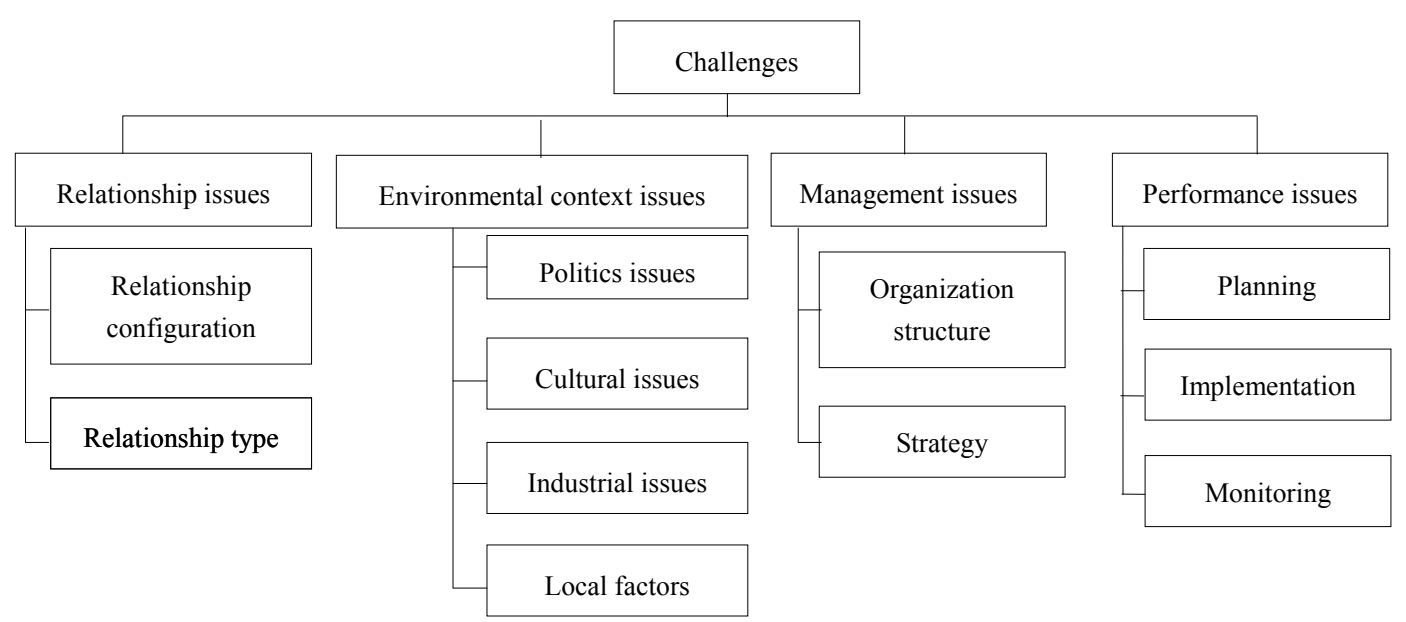

Figure 8. Framework in integrating stakeholders into MNC management process

\section{Conclusion}

In this paper wepresented the different challenges that the MNC faces in integrating stakeholders into management process to achieve sustainable development in a volatile market place. We presented these challenges in a conceptual framework incorporating both internal and external factors. The important elements of this framework are grouped into four categories: relationship, environmental context, management including structure and strategy issues and stakeholder engagement performance.

The configuration of relationship between headquarters, local stakeholders and global stakeholders raises challenges for multinational firms (Ward \& Leon, 1996). The network structure increases complexity in value analysis and the stakeholder engagement process and consequently for performance measurement (Keivanpour, Ait-Kadi \& Mascle, 2013; Mikalsen \& Jentoft, 2001). Dealing with local stakeholders requires more authority and flexibility in subsidiaries but this issue can raise some challenges for headquarters in monitoring and the strategic decision making process.

Stakeholder engagement needs agility and quick responsiveness in organizational structure. As a result, a degree of contingency in organizational structure of multinational firms is needed when considering an active role for stakeholders, but designing such structure might be challenging for multinational companies (Romano et al., 2001).

The varieties of non-equity stakeholders and the degree of participation in communications and partnership can influence the strategic choice of multinational companies. As the local implementer, each MNC subsidiary needs to deal with local suppliers to meet the local market needs in production. For the global market, an MNC needs to establish appropriate strategies for interaction with global competitors and global players.

Dealing with different stakeholders in different socio-economic, cultural and political backgrounds raises many challenges for multinational firms. These challenges can be addressed while respecting local and global ethical concerns with adequate communication channels. Without doubt, involvement of stakeholders requires appropriate dialogue and negotiation with interest groups. Different cultural and political frameworks complicate these negotiation, bargaining, and dialogues.

Based on the plan-do-check-action (PDCA) cycle, some challenges may occur in the phase including planning, execution and mentoring. Other challenges, such as the clear definition of goal and objectives and value definition from a stakeholder's perspectives, exist in the planning phase. In the execution phase, the identification of key stakeholders and their priorities, and in the monitoring phase, identifying performance metrics are a source of conflict. Future research could include empirically testing the proposed conceptual framework.

\section{References}

Abd Karim, S. B., Abdul Rahman, H., Ali Berawi, M., \& Jaapar, A. (2007). A Review of the Issues and Strategies of stakeholder Management in the construction Industry. Management in Construction and Researchers Association (MICRA) Meetings and Conference, 28-29. 
Ackoff, R., \& Churchman, C. (1947). An experimental definition of personality. Philosophy of Science, 14, 304-332. http://dx.doi.org/10.1086/286958

Ackoff, R., \& Russel, L. (1970). A Concept of Corporate Planning. New York: Wiley.

Al-Azad, M. S., Mohiuddin, M., \& Rashid, M. M. (2010). Knowledge Transfer in Offshore Outsourcing and International Joint Ventures (IJVs): A Critical Literature Review from Cross-Cultural Context. Global Journal of Strategies and Governance, 1(1), 41-67.

Allison, G. T. (1971). The Essence of Decision. Boston: Brown.

Amaeshi, K. M., \& Crane. A. (2006). Stakeholder Engagement: A Mechanism for Sustainable Aviation. Corporate Social Responsibility and Environmental Management, 13(5), 245-260. http://dx.doi.org/10.1002/csr.108

Amaeshi, K. (2010). Stakeholder Management: Theoretical Perspectives and Implications. In E. Chinyio \& P. Olomolaiye (Eds.), Construction Stakeholder Management. Oxford, UK: Wiley-Blackwell. http://dx.doi.org/10.1002/9781444315349.ch2

Ansoff, H. I. (1965). Corporate Strategy. New York: McGraw Hill.

Astley, W. G. (1984). Toward an Appreciation of Collective Strategy, Academy of Management Review, 9(3), 526-535. http://dx.doi.org/10.5465/AMR.1984.4279700

Barton, S. L., \& Gordon, P. J. (1987). Corporate Strategy: Useful Perspective for the Study of Capital Structure? The Academy of Management Review, 12(1), 67-75. http://dx.doi.org/10.5465/AMR.1987.4306479

Berman, S., Wicks, A. C., Kotha, S., \& Jones, T. (1999). Does stakeholder orientation matter? An empirical examination of the relationship between stakeholder management models and firm financial performance. Academy of Management Journal, 42(5), 488-506. http://dx.doi.org/10.2307/256972

Birkinshaw, J., \& Hood, N. (1998). Multinational Subsidiary Evolution: Capability and Charter Change in Foreign Owned Subsidiary Companies. Academy of Management Review, 23(4), 773-795. http://dx.doi.org/10.5465/AMR.1998.1255638

Birkinshaw, J. M., \& Morrison A. J. (1995). Configurations of Strategy and Structure in Subsidiaries of Multinational Corporations. Journal of International Business Studies, 26(4), 729-753. http://dx.doi.org/10.1057/palgrave.jibs.8490818

Boulouta, I., \& Pitelis, C. N. (2013). Who needs CSR? The impact of corporate social responsibility on national competitiveness. Journal of Business Ethics, 1-16. http://dx.doi.org/10.1007/s10551-013-1633-2

Bower, J. (1972). Managing the Resource Allocation Process: A Study of Corporate Planning and Investment. Illinois: Irwin, Homewood.

Brenner, S. N., \& Cochran, P. (1991). The stakeholder theory of the firm: Implications for business and society theory and research. Paper presented at the annual meeting of the International Association for Business and Society, Sundance, UT.

Brickson, S. L. (2005). Organizational identity orientation: forging a link between Organizational Identity and Organizations' Relations with Stakeholders. Administrative Science Quarterly, 50(4), 576-609.

Castro, G. M., Verde, M. D., Salvadó, J. A., \& Navas-López, J. E. (2013). Linking human, technological, and relational assets to technological innovation: exploring a new approach. Knowledge Management Research \& Practice, 11(1), 123-132. http://dx.doi.org/10.1057/kmrp.2013.8

Chandler, A. D. (1962). Strategy and Structure: Chapters in the History of the Industrial Enterprises. Cambridge, Mass: The MIT Press.

Chew, J. (2004). Managing MNC Expatriates through Crises: A Challenge for International Human Resource Management. Research and Practice in Human Resource Management, 12(2), 1-30.

Colakoglu, S., Tarique, I., \& Caligiuri, P. (2009). Towards a conceptual framework for the relationship between subsidiary staffing strategy and subsidiary performance. The International Journal of Human Resource Management, 20(6), 1291-1308. http://dx.doi.org/10.1080/09585190902909822

Crilly, D. (2011). Predicting stakeholder orientation in the multinational enterprise: A mid-range theory. Journal of International Business Studies, 42(5), 694-717. http://dx.doi.org/10.1057/jibs.2010.57

Cyert, R. M., \& James, G. M. (1963). A Behavioral Theory of the Firm. Prentice Hall: New Jersey. 
Gary, D. G., Chun, R., \& Kamins, M. A. (2009). Reputation gaps and the performance of service organizations. Strategic Management Journal, 31(5), 530-546.

Donaldson, T., \& Preston, L. E. (1995). The Stakeholder Theory of the Corporation: Concepts, Evidence, and Implications. The Academy of Management Review, 20(1), 65-91. http://dx.doi.org/10.5465/AMR.1995.9503271992

Enderle, G. (1999). International Business Ethics: Challenges and Approaches. Notre Dame, Indiana: University of Notre Dame Press.

Ferraro, G. P. (2009). The cultural dimension of international business (6th ed.). USA: Prentice Hall PTR.

Fischhoff, B. (2000). Value elicitation: is there anything in there? In Connolly, T., Arkes, H. R., \& Hammond, K. R. (Eds.), Judgement and Decision-making (pp. 517-543). CUP, Cambridge: An Interdisciplinary Reader.

Freeman, R. E., Wicks, A. C., \& Parmar, B. (2004). Stakeholder theory and The Corporate objective revisited, Organization Science, 15(3), 364-369. http://dx.doi.org/10.1287/orsc.1040.0066

Freeman, R. E., \& McVea, J. (2001). A Stakeholder Approach to Strategic Management. Darden Business School Working Paper No. 01-02. Retrieved from http://ssrn.com/abstract=263511 or http://dx.doi.org/10.2139/ssrn.263511

Freeman, R. E. (1984). Strategic management: A stakeholder approach. Boston: Pitman/Ballinger (Harper Collins).

Freeman, R. E., \& Reed, D. L. (1983). Stockholders and stakeholders: A new perspective on corporate governance. California Management Review, 25(3), 93-94. http://dx.doi.org/10.2307/41165018

Frooman, J. (1999). Stakeholder Influence Strategies. Academy of Management Review, 24(2), 191-205. http://dx.doi.org/10.5465/AMR.1999.1893928

Frynas, J. G. (2005). The false developmental promise of Corporate Social Responsibility: evidence from multinational oil companies. International Affairs, 81(3), 581-598. http://dx.doi.org/10.1111/j.1468-2346.2005.00470.x

Gable, C., \& Shireman, B. (2005). Stakeholder Engagement: A Three-Phase Methodology. Environmental Quality Management, 9-24. http://dx.doi.org/10.1002/tqem.20044

Geringer, J. M., Beamish, P. W., \& Dacosta, R. C. (1989). Diversification strategy and internationalization: Implications for MNE performance. Strategic Management Journal, 10(2), 109-119. http://dx.doi.org/10.1002/smj.4250100202

Ghoshal, S. (1989). Internal differentiation within multinational corporations. Strategic Management Journal, 10(4), 323-337. http://dx.doi.org/10.1002/smj.4250100403

Grant, R. M. (2003). Strategic planning in a turbulent environment: evidence from the oil majors. Strategic Management Journal, 24(6), 491-517. http://dx.doi.org/10.1002/smj.314

Harrison, J. S., \& St. John, C. H. (2009). Foundations in Strategic Management (5th ed.). USA: Cengage Learning.

Hedlund, G., Ghoshal, S., \& Westney, D. E. (1993). Assumptions of Hierarchy and Heterarchy: An Application to the Multinational Corporation. In Ghoshal, S., \& Westney, D. E. (Eds.), Organization Theory and the Multinational Corporation. New York: St. Martin's Press.

Husted, W. B., \& Allen, D. B. (2006). Corporate Social Responsibility in the Multinational Enterprise: Strategic and Institutional Approaches. Journal of International Business Studies, 37(6), 733-746. http://dx.doi.org/10.1057/palgrave.jibs.8400227

Inglehart, R., Basanez, M., \& Menendez, A. M. (1998). Human Values and Beliefs: A Cross-cultural Source book. Political, Religious, Sexual, and Economic Norms in 43 Societies: Findings from the 1990-1993 World Values Survey (Ann Arbor, MI: University of Michigan Press).

Jensen, M. C. (2002). Value maximization, stakeholder theory, and the corporate objective function. Business Ethics Quarterly, 12(2), 235-256. http://dx.doi.org/10.2307/3857812

Jones, T. M. (1995). Instrumental stakeholder theory: A synthesis of ethics and economics. Academy of Management Review, 20(2), 404-437. http://dx.doi.org/10.5465/AMR.1995.9507312924 
Kang, J. (2013). The relationship between corporate diversification and corporate social performance. Strategic Management Journal, 34(1), 94-109.

Kaptein, M. (2004). Business Codes of Multinational Firms: What Do They Say? Journal of Business Ethics, 50(1), 13-31.

Kaptein, M., \& Wempe, J. (2002). The balanced company: A theory of corporate integrity. Oxford: Oxford University Press.

Karuranga, E., Asti, F., Musonera, E., \& Mohiuddin, M. (2011). The Impact of Foreign Direct Investment on Financial Performance: Results from the M\&A Experiences of Canadian Firms from 1999 to 2005. International Review of Business Research Papers, 7(4), 25-45.

Katz, D., \& Kahn, R. (1966). The social psychology of organizations. New York: Wiley.

Keivanpour, S., Ait-Kadi, D., \& Mascle, C. (2013). Oward a Strategic Approach to End-of-Life Aircraft Recycling Projects: A Research Agenda in Transdisciplinary Context. Journal of Management and Sustainability, 3(3), 76-94. http://dx.doi.org/10.5539/jms.v3n3p76

Kennerly, M. S. (2010). EBay v. Newmark: Al Franken Was Right, Corporations Are Legally Required to Maximize Profits. Retrieved from http://www.litigationandtrial.com/2010/09/articles/series/special-comment/ebay-v-newmark-al-franken-wa s-right-corporations-are-legally-required-to-maximize-profits/

Key, S. (1999). Toward a new theory of the firm: a critique of stakeholder theory. Management Decision, 37(4), 317-328. http://dx.doi.org/10.1108/00251749910269366

Kim, B., Prescott, J. E., \& Kim, S. M. (2005). Differentiated governance of foreign subsidiaries in transnational corporations: An agency theory perspective. Journal of International Management, 11(1), 43-66. http://dx.doi.org/10.1016/j.intman.2004.11.004

Kimiagari, S., \& Montreuil, B. (2013). Market Deployment Roadmap Planning: A Methodological Framework, Proceedings of the Academy of International Business-US Midwest 2013 Annual Meeting-Illinois (US), February 27-March 1, 2013.

Kimiagari, S., Keivanpour, S., \& Mohiuddin, M. (2013). International Strategic Alliances and Knowledge Transfer in Upstream Oil and Gas sector: Prospects for the National Iranian Oil Company (NIOC). Proceedings of the Academy of International Business-North East chapter (AIB-NE) conference, October 10-12, 2013, Connecticut, USA.

Koopman, P. L. (1990). New Information Technology and Organisational Decision Making. The Irish Journal of Psychology, 11(2), 186-210. http://dx.doi.org/10.1080/03033910.1990.105577911

Laplume, A. O., Sonpar, K., \& Litz, R. A. (2008). Stakeholder Theory: Reviewing a Theory That Moves Us. Journal of Management, 34(6), 1152-1189. http://dx.doi.org/10.1177/0149206308324322

Lazonick, W., \& O'Sullivan, M. (2000). Maximizing shareholder value: a new ideology for corporate governance. Economy and Society, 29(1), 13-35. http://dx.doi.org/10.1080/030851400360541

Matei, M., \& Mohiuddin, M. (2010). Étude Qualitative Sur les Dimensions du Concept de Centre de L'Excellence de la Filiale à L'Étranger: Une Analyse du Contenu de la Littérature Scientifique par Nvivo (Qualitative Study on Dimensions of 'Centre of Excellence' of Foreign Subsidiaries: A Content Analysis of Scientific Literature by Nvivo). Global Journal of Strategies and Governance, 2(1), 73-90.

Michailides, T. P., \& Lipsett, M. G. (2012). Surveying Employee Attitudes on Corporate Social Responsibility at the Frontline Level of an Energy Transportation Company. Corporate Social Responsibility and Environmental Management. http://dx.doi.org/10.1002/csr.1291

Mikalsen, K. H., \& Jentoft, S. (2001). From user-groups to stakeholders? The public interest in fisheries management. Marine Policy, 25(4), 281-292. http://dx.doi.org/10.1016/S0308-597X(01)00015-X

Mitchell, R. K., Agle, B. R., \& Wood, D. J. (1997). Toward a theory of stakeholder identification and salience: Defining the principle of who and what really counts. Academy of Management Review, 22(4), 853-886, http://dx.doi.org/10.5465/AMR.1997.9711022105

Moen, R., \& Norman, C. (2006). Evolution of the PDCA Cycle. Retrieved from http://www.kaizensite.com

Mockler, R. J. (2002). Multinational strategic management: An integrative entrepreneurial context-specific process. International business press (IBS). 
Porter, M. E. (1986). Competition in global industries. Boston, MA: Harvard Business School Press.

Reimann, F., Ehrgott, M., Kaufmann, L., \& Carter, C. R. (2012). Local stakeholders and local legitimacy: MNEs' social strategies in emerging economies. Journal of International Management, 18(1), 1-17. http://dx.doi.org/10.1016/j.intman.2011.06.002

Riahi-Belkaoui, A. (2003). Intellectual capital and firm performance of US multinational firms A study of the resource-based and stakeholder views. Journal of Intellectual Capital, 4(2), 215-226. http://dx.doi.org/10.1108/14691930310472839

Rodriguez, P., Siegel, D. S., Hillman, A., \& Eden, L. (2006). Three Lenses on the Multinational Enterprise: Politics, Corruption and Corporate Social Responsibility. Journal of International Business Studies, 37(6), 838-849. http://dx.doi.org/10.1057/palgrave.jibs.8400227

Romano, C. A., Tanewski, G. A., \& Smyrnios, K. X. (2001). Capital structure decision making: A model for family business. Journal of Business Venturing, 16(3), 285-310. http://dx.doi.org/10.1016/S0883-9026(99)00053-1

Ruf, B. M., Muralidhar, K., Brown, R. M., \& Janney, J. J. (2001). An empirical investigation of the relationship between change in corporate social performance and financial performance: a stakeholder theory perspective. Journal of Business Ethics, 32(2), 143-156. http://dx.doi.org/10.1023/A:1010786912118

Rugman, A. M. (2005). The regional multinationals MNEs and Global strategic management. Cambridge university press. http://dx.doi.org/10.1017/CBO9780511614071

Shrivastava, P., \& Grant, J. H. (1985). Empirically Derived Models of Strategic Decision-making Processes. Strategic Management Journal, 6(2), 97-113. http://dx.doi.org/10.1002/smj.4250060202

Simon, H. T. (1945). Administrative Behavior. New York: the Free Press.

Sultana, M. A., Rashid, M. M., Mohiuddin, M., \& Mazumder, M. N. H. (2013). Cross-cultural Management and Organizational Performance: A Content Analysis Perspective. International Journal of Business and Management, 8(8), 113-146. http://dx.doi.org/10.5539/ijbm.v8n8p133

Svendsen, A. C., \& Laberge, M. (2005). Convening Stakeholder Networks. A New Way of Thinking, Being and Engaging. The Journal of Corporate Citizenship, 19, 1-16.

Thompson, J. K., Wartick, S. L., \& Smith, H. L. (1991). Integrating corporate social performance and stakeholder management: Implications for a research agenda in small business. Research in Corporate Social Performance and Policy, 12(1), 207-230.

Thompson, J. D. (1967). Organizations in Action: Social Science Bases of Administrative Theory. Transaction Publishers.

Tompkins, E. L., Few, R., \& Brown, K. (2008). Scenario-based stakeholder engagement: Incorporating stakeholders' preferences into coastal planning for climate change. Journal of Environmental Management, 88(4), 1580-1592. http://dx.doi.org/10.1016/j.jenvman.2007.07.025

Wang, Y. B. (2010). Towards a New Science of Governance. Transnational Corporations Review, 2(2), 52-56. http://dx.doi.org/10.5148/tncr.2010.1049

Ward, P. T. B., \& Leon, D. J. (1996). Configurations of manufacturing strategy, business strategy, environment and structure. Journal of Management, 22(4), 597-626. http://dx.doi.org/10.1177/014920639602200404

Wheelwright, S. C. (1984). Strategy, Management, and Strategic Planning Approaches. Strategic Management Journal, 14(1), 19-33.

Zyglidopoulos, S. C. (2002). The Social and Environmental Responsibilities of Multinationals: Evidence from the Brent Spar Case. Journal of Business Ethics, 36(1-2), 141-151. http://dx.doi.org/10.1023/A:1014262025188

\section{Copyrights}

Copyright for this article is retained by the author(s), with first publication rights granted to the journal.

This is an open-access article distributed under the terms and conditions of the Creative Commons Attribution license (http://creativecommons.org/licenses/by/3.0/). 